\title{
Efek Ekstrak Etanol Daun Kesum (Polygonum minus Huds.) sebagai Antifungi terhadap Trichophyton rubrum
}

\author{
Shintya Dewi ${ }^{1}$, Syarifah NYRS Asseggaf ${ }^{2}$, Diana Natalia ${ }^{3}$, Mahyarudin $^{4}$
}

\begin{abstract}
Abstrak
Dermatofitosis adalah penyakit akibat kolonisasi jamur dermatofit dengan agen penyebab terbanyak yaitu jamur Trichophyton rubrum. Daun kesum (Polygonum minus Huds.) mengandung senyawa-senyawa metabolit sekunder yang dapat digunakan sebagai antijamur. Tujuan penelitian ini adalah menentukan efek ekstrak etanol daun kesum sebagai antifungi terhadap Trichophyton rubrum, menentukan konsentrasi ekstrak etanol daun kesum yang efektif sebagai antifungi dan menentukan diameter zona hambatan ekstrak etanol daun kesum terhadap Trichophyton rubrum. Metodologi penelitian ini merupakan eksperimental murni. Analisis fitokimia pada daun kesum menggunakan uji KLT. Aktivitas antifungi diuji dengan metode difusi cakram. Itrakonazol digunakan sebagai kontrol positif dan DMSO $10 \%$ digunakan sebagai kontrol negatif. Hasil penelitian pada skrining fitokimia didapatkan flavonoid, saponin, alkaloid, terpenoid, dan fenol. Ekstrak etanol daun kesum memiliki aktivitas antifungi pada konsentrasi 5\%; 10\%; 20\%; 40\%; $80 \%$. Respon hambatan yang terbentuk yaitu pada konsentrasi $5 \%$ dengan kategori hambatan sedang (9 mm); konsentrasi $10 \%$ dengan kategori sedang $(9,75 \mathrm{~mm})$; konsentrasi $20 \%$ dengan kategori kuat $(14 \mathrm{~mm})$; konsentrasi $40 \%$ dengan kategori kuat $(15 \mathrm{~mm})$; dan konsentrasi $80 \%$ dengan kategori sangat kuat $(21 \mathrm{~mm})$. Simpulan dari penelitian ini yaitu ekstrak etanol daun kesum memiliki aktivitas antifungi terhadap Trichophyton rubrum dan konsentrasi yang efektif yaitu $20 \%$.
\end{abstract}

Kata kunci: antifungi, ekstrak etanol daun kesum, Trichophyton rubrum

\section{Abstract}

Dermatophytosis is a disease caused by colonization of dermatophyte fungi with the most common causative agents is Trichophyton rubrum. The leaves of kesum (Polygonum minus Huds.) containing secondary metabolite compounds that can be used as antifungal. The objective of this study was to determine the antifungal actvity of ethanol extract of kesum leaves on Trichophyton rubrum, to determine the concentration of ethanol extract of kesum leaves as an antifungal and to determine the inhibition zone diameters of ethanol extract of kesum leaves against Trichophyton rubrum. Method of this study was an experimental study. Phytochemical analysis of kesum leaves use the TLC test. Antifungal activity was determined using disc diffusion methods. Itraconazple was used as the positive control and 10\% DMSO was used as the negative control. Result of phytochemical screening showed that kesum leaves contain flavonoids, saponins, alkaloids, terpenoids, and phenols. Ethanol extract of kesum leaves had antifungal activity at a concentration of $5 \% ; 10 \% ; 20 \% ; 40 \% ; 80 \%$. The inhibitory zone that formed was at a concentration of $5 \%$ with the medium category $(9 \mathrm{~mm}) ; 10 \%$ concentration with the medium category $(9.75 \mathrm{~mm}) ; 20 \%$ concentration with a strong category (14 mm); 40\% concentration with a strong category (15 $\mathrm{mm}$ ); $80 \%$ concentration with a very strong category $(21 \mathrm{~mm})$. The conclusion is ethanol extract of kesum leaves had antifungal activity against Trichophyton rubrum and an effective concentration was at $20 \%$.

Keywords: antifungal, ethanol extract of kesum leaves, Trichophyton rubrum

Affiliasi penulis: 1. Prodi Pendidikan Dokter FK Untan (Fakultas Kedokteran Universitas Tanjungpura). 2. Departemen Farmakologi FK Untan. 3. Departemen Parasitologi FK Untan. 4. Departemen Mikrobiologi FK Untan.
Korespondensi :Diana Natalia, Email:

diananatalia@medical.untan.ac.id Telp: 081382311690 


\section{PENDAHULUAN}

Dermatofitosis adalah jenis penyakit akibat kolonisasi jamur dermatofit yang menyerang stratum korneum kulit, rambut dan kuku pada manusia. ${ }^{1}$ Penyakit kulit ini sering terjadi di negara beriklim tropis, seperti di Indonesia. Suhu dan kelembapan yang tinggi dapat mendukung pertumbuhan jamur. ${ }^{2}$ Dermatofitosis juga diketahui dapat menular dan menyebabkan infeksi kronis pada individu sehat. ${ }^{3}$

Dermatofitosis tersebar di seluruh dunia dengan prevalensi berbeda-beda pada tiap negara. ${ }^{4}$ Penelitian terhadap insiden dari infeksi dermatofit, didapatkan bahwa $20 \%$ orang dari seluruh dunia mengalami infeksi kutaneus dengan infeksi tinea korporis merupakan tipe yang paling dominan dan diikuti dengan tinea kruris dan pedis. ${ }^{5}$

Insidensi penyakit kulit yang disebabkan oleh jamur di RSUP Prof. Dr. R. D. Kandou Manado periode Januari hingga Desember 2012 didapatkan sebanyak 65 kasus. $^{6}$ Distribusi jumlah kasus dermatofitosis pada Januari hingga Desember 2013 di RSUP Prof. Dr. R. D. Kandou Manado meningkat dari tahun sebelumnya yaitu menjadi 153 kasus. Distribusi kasus dermatofitosis berdasarkan umur didapatkan golongan terbesar pada usia 45-64 tahun sebanyak $32,7 \% .^{7}$ Kasus dermatofitosis ini dapat ditemukan hampir di seluruh daerah Indonesia, hal ini dikarenakan iklim dan kondisi geografis di Indonesia yang memudahkan pertumbuhan jamur. ${ }^{8}$

Trichophyton rubrum merupakan agen paling umum penyebab seluruh penyakit kulit infeksi jamur di dunia. Jamur ini dapat menginfeksi kulit manusia dan kuku melalui degradasi keratin. Keratin adalah protein berserat yang merupakan komponen struktural utama dari kulit manusia dan kuku. Mekanisme dari Trichophyton rubrum yaitu menyerang melalui stratum korneum, lapisan terluar dari epidermis, untuk mendapatkan keratin. ${ }^{3}$

Pengobatan dermatofitosis dapat diberikan secara topikal maupun sistemik. Pemberian obat golongan azol dapat digunakan pada kasus dermatofitosis, namun obat tersebut memiliki beberapa efek yang cukup berbahaya yaitu dapat menyebabkan toksisitas hati terutama pada penggunaan dalam jangka waktu panjang. ${ }^{9}$ Kasus resistensi dan toksisitas yang disebabkan oleh antifungi sintetik membuat banyak orang mulai mencoba menggunakan obat-obat tradisional dari tumbuhan herbal yang diaharapkan dapat lebih aman dan murah, salah satu tanaman yang dapat digunakan adalah daun kesum.

Daun kesum (Polygonum minus Huds.) merupakan tanaman khas Kalimantan Barat. Tanaman ini tumbuh di daerah tropis dan subtropis, yaitu pada tempat yang hangat dan lembab, oleh karena itu tanaman ini banyak ditemukan di Kalimantan Barat dan telah banyak dimanfaatkan oleh masyarakat sekitar sebagai bahan makanan. Daun kesum memiliki potensi sebagai antifungi, hal ini dapat dilihat dari kandungan yang terdapat di dalamnya. ${ }^{10}$

Berdasarkan kajian fitofarmaka, tanaman kesum memiliki aktivitas antiviral, antibakteri, antijamur, antioksidan, antikanker dan antiulcer. Tanaman kesum mengandung senyawa-senyawa golongan fenolik, flavonoid, alkaloid, tanin, dan terpenoid. $^{11,12}$ Beberapa penelitian pada daun kesum menunjukkan bahwa pada senyawa golongan flavonoid terdapat senyawa rutin dan kuersetin, sedangkan pada senyawa fenolik terdapat asam koumarat dan asam galat. ${ }^{13}$ Aktivitas senyawasenyawa tersebut dapat digunakan sebagai antifungi yang bekerja dengan cara mengganggu fungsi membran sitoplasma. ${ }^{14,15}$ Berdasarkan latar belakang tersebut, maka penulis bermaksud melakukan penelitian terhadap efek ekstrak etanol daun kesum (Polygonum minus Huds.) sebagai antifungi terhadap Trichophyton rubrum.

\section{METODE}

Penelitian telah dilakukan di laboratorium non mikroskopik dan mikroskopik Fakultas Kedokteran Universitas Tanjungpura dari April 2017 sampai September 2018. Metode penelitian bersifat eksperimental murni dengan metode Rancangan Acak Lengkap (RAL). Variabel bebas yang digunakan adalah ekstrak etanol daun kesum (Polygonum minus Huds.) dengan konsentrasi 5\%, 10\%, 20\%, 40\%, 80\%; dan variabel terikat adalah jamur Trichophyton rubrum.

Ekstrak etanol daun kesum diperoleh melalui proses maserasi menggunakan etanol 96\%. Filtrat daun kesum (Polygonum minus Huds.) yang diperoleh, disatukan, dan dipekatkan dengan menggunakan 
rotary evaporator pada suhu $40^{\circ} \mathrm{C}-50^{\circ} \mathrm{C}$ hingga diperoleh ekstrak kental. Ekstrak kental etanol daun kesum dilakukan skrining fitokimia menggunakan Kromatografi Lapis Tipis (KLT).

Pengujian daya hambat esktrak etanol daun kesum terhadap pertumbuhan Trichophyton rubrum dilakukan dengan metode difusi menggunakan kertas cakram. Aktivitas antifungi ditunjukkan dengan terbentuknya area jernih pada kertas cakram. Data hasil penelitian yang diperoleh selanjutnya diuji normalitas dan variansi data (Uji Saphiro Wilk dan Homogenity of Variance). Data yang berdistribusi dan bervariasi normal dilakukan uji one way analysis of variance (Anova) dengan taraf kepercayaan 95\%. Uji Anova yang menghasilkan $\mathrm{p}<0,05$ dilanjutkan dengan melakukan analisis Post Hoc Least Significane Difference (LSD).

\section{HASIL}

Hasil skrining fitokimia ekstrak etanol daun kesum mengandung senyawa metabolit sekunder yaitu flavonoid, saponin, alkaloid, terpenoid, dan fenolik. Hasil skrining fitokimia ekstrak etanol daun kesum dapat dilihat pada Tabel 1.

Tabel 1. Hasil uji fitokimia ekstrak etanol daun kesum (Polygonum minus huds.) dengan kromatografi lapis tapis

\begin{tabular}{|c|c|c|c|c|}
\hline No & $\begin{array}{l}\text { Metabolit } \\
\text { sekunder }\end{array}$ & Pereaksi & Hasil & Keterangan \\
\hline 1 & Flavonoid & Serium Sulfat & + & $\begin{array}{l}\text { Terbentuk } \\
\text { warna } \\
\text { kuning yang } \\
\text { pekat }\end{array}$ \\
\hline 2 & Saponin & Uji kocok & + & $\begin{array}{l}\text { Terbentuk } \\
\text { busa setelah } \\
\text { dikocok }\end{array}$ \\
\hline 3 & Alkaloid & Dragendroff & + & $\begin{array}{l}\text { Terbentuk } \\
\text { endapan } \\
\text { kuning }\end{array}$ \\
\hline 4 & Terpenoid & $\begin{array}{l}\text { Liebermann- } \\
\text { Burchard }\end{array}$ & + & $\begin{array}{l}\text { Terbentuk } \\
\text { warna } \\
\text { merah }\end{array}$ \\
\hline 5 & Fenolik & $\mathrm{FeCl}_{3}$ & + & $\begin{array}{l}\text { Terbentuk } \\
\text { warna biru } \\
\text { kehitaman }\end{array}$ \\
\hline
\end{tabular}

Aktivitas antifungi ekstrak etanol daun kesum dapat diamati melalui diameter zona hambat yang terbentuk pada media uji yang telah diletakkan dengan kertas cakram. Hasil pengamatan uji aktivitas antifungi ekstrak etanol daun kesum terhadap Trichophyton rubrum setelah inkubasi 7 hari pada suhu $37^{\circ} \mathrm{C}$ yaitu rata-rata respon hambatan yang terbentuk pada konsentrasi $5 \%$ adalah $9 \mathrm{~mm}$ dengan kategori hambatan sedang; konsentrasi $10 \%$ adalah 9,75 mm dengan kategori sedang; konsentrasi $20 \%$ adalah 14 mm dengan kategori kuat; konsentrasi 40\% adalah 15 $\mathrm{mm}$ dengan kategori kuat; konsentrasi $80 \%$ adalah 21 $\mathrm{mm}$ dengan kategori sangat kuat; kontrol positif adalah 48,5 mm; dan tidak ada zona hambat yang terbentuk pada kontrol negatif. Hasil uji aktivitas antifungi dapat dilihat pada Tabel 2.

Tabel 2. Hasil uji aktivitas antifungi ekstrak etanol daun kesum (Polygonum minus Huds.) terhadap Trichophyton rubrum

\begin{tabular}{|c|c|c|c|c|c|}
\hline \multirow{3}{*}{$\begin{array}{c}\text { Konsen- } \\
\text { trasi }\end{array}$} & \multicolumn{5}{|c|}{ Diameter Zona Hambat (mm) } \\
\hline & \multicolumn{5}{|c|}{ Pengulangan ke- } \\
\hline & $I$ & II & III & IV & Rerata \\
\hline \multirow[t]{2}{*}{$5 \%$} & 10 & 14 & 12 & 0 & $9 \pm$ \\
\hline & & & & & 6,22 \\
\hline \multirow[t]{2}{*}{$10 \%$} & 0 & 13 & 14,5 & 11,5 & $9,75 \pm$ \\
\hline & & & & & 6,61 \\
\hline \multirow[t]{2}{*}{$20 \%$} & 12 & 14 & 14 & 16 & $14 \pm$ \\
\hline & & & & & 1,63 \\
\hline \multirow[t]{2}{*}{$40 \%$} & 12 & 12 & 20 & 16 & $15 \pm$ \\
\hline & & & & & 3,83 \\
\hline \multirow[t]{2}{*}{$80 \%$} & 20 & 21 & 20 & 23 & $21 \pm$ \\
\hline & & & & & 1,41 \\
\hline Kontrol (-) & 0 & 0 & 0 & 0 & 0 \\
\hline \multirow[t]{2}{*}{ Kontrol (+) } & 50 & 50 & 48 & 46 & $48,5 \pm$ \\
\hline & & & & & 1,91 \\
\hline
\end{tabular}

Uji statistik dilakukan setelah hasil uji aktivitas antifungi diperoleh. Hasil uji normalitas Saphiro-Wilk, hasil yang diperoleh menunjukkan data berdistribusi normal yang dapat dilihat dari signifikansi $>0,05$. Hasil statistik uji varians Levene memiliki nilai signifikansi $>0,05$ yaitu 0,067; maka varians dari kelompok data yang dibandingkan adalah sama.

Uji One-Way ANOVA dilanjutkan setelah data berdistribusi normal dan memiliki variansi data yang 
sama. Hasil uji One-Way ANOVA memiliki nilai signifikansi 0,000; dikarenakan nilai signifikansi $<0,05$; maka data yang diperoleh memiliki perbedaan bermakna antar diameter zona hambat yang terbentuk dan kelompok perlakuan.

Analisis Post Hoc Least Significane Difference (LSD) didapatkan adanya perbedaan bermakna antara kontrol positif dengan konsentrasi 5\%, 10\%, 20\%, $40 \%$, dan $80 \%$; serta perbedaan bermakna antara konsentrasi $80 \%$ dengan konsentrasi $20 \%$, 10\%, dan $5 \%$; hal tersebut dikarenakan nilai signifikansinya $<0,05$. Tidak terdapat perbedaan bermakna antara konsentrasi $40 \%$ dengan konsentrasi $80 \%$, 20\%, 10\%, dan 5\%; hal ini dikarenakan nilai signifikansinya $>0,05$.

\section{PEMBAHASAN}

Uji aktivitas antifungi ekstrak etanol daun kesum pada penelitian ini menggunakan metode difusi cakram Kirby-Bauer. Piringan yang berisi agen antimikrob diletakkan pada media agar yang telah ditanami mikroorganisme yang akan berdifusi pada media agar tersebut. Area jernih mengindikasikan adanya hambatan pertumbuhan mikroorganisme oleh agen antimikrob pada permukaan media agar. ${ }^{16} \mathrm{Uji}$ ini dilakukan dengan tujuan untuk mengetahui adanya aktivitas antifungi dari ekstrak etanol daun kesum terhadap pertumbuhan jamur Trichophyton rubrum. Penelitian ini menggunakan 5 kelompok perlakuan dengan variasi konsentrasi ekstrak etanol daun kesum $5 \%, 10 \%, 20 \%, 40 \%$, dan $80 \%$ serta dua kontrol yaitu kontrol positif dan kontrol negatif.

Kontrol positif yang digunakan adalah itrakonazol $8 \mu \mathrm{g} /$ disk, itrakonazol digunakan sebagai kontrol positif karena merupakan antifungi yang sensitif terhadap pertumbuhan jamur golongan dermatofita. Kontrol negatif yang digunakan adalah DMSO $10 \%$ yang akan menunjukkan hasil negatif dan tidak memberikan aktivitas antifungi. Hasil kontrol negatif yang diperoleh pada uji aktivitas antifungi diperoleh bahwa tidak adanya aktivitas antifungi dengan tidak terbentuknya zona hambat di sekitar cakram. Zona hambat merupakan zona bening yang terbentuk di sekitar kertas cakram yang menunjukkan adanya penghambatan pada pertumbuhan jamur. Zona hambat yang tidak terbentuk pada kontrol negatif disebabkan karena tidak adanya senyawa metabolit sekunder. Sedangkan, kontrol positif itrakonazol memberikan hasil rerata diameter zona hambat 48,5 $\mathrm{mm}$, zona hambat tersebut dikategorikan sensitif.

Uji aktivitas antifungi yang dilakukan dengan variasi konsentrasi uji 5\%, 10\%, 20\%, 40\%, dan $80 \%$ didapatkan adanya zona hambat pada seluruh konsentrasi tersebut. Berdasarkan hasil pengamatan uji aktivitas antifungi ekstrak etanol daun kesum terhadap jamur Trichophyton rubrum diperoleh nilai rerata diameter zona hambat yang berkisar antara 9 hingga $21 \mathrm{~mm}$. Penelitian sebelumnya menyatakan bahwa ekstrak etanol rimpang lengkuas dapat digunakan untuk menghambat pertumbuhan Trichphyton rubrum pada konsentrasi 30\% dengan diameter zona hambat sebesar $3 \mathrm{~mm} .{ }^{17}$ Penelitian lainnya juga menunjukkan ekstrak etanol umbi bawang dayak dapat menghambat Trichophyton rubrum pada konsentrasi $15 \%$ dengan diameter zona hambat sebesar $15,06 \mathrm{~mm}^{18}$

Aktivitas antifungi dikategorikan lemah apabila memiliki diameter zona hambat 0-4 mm, dikategorikan sedang jika diameter zona hambat 5-10 mm, kuat apabila diameter zona hambat 11-20 mm, dan sangat kuat jika diameter zona hambat $>20 \mathrm{~mm}^{19}$ Berdasarkan kategori tersebut, tingkat penghambatan dari ekstrak etanol daun kesum terhadap Trichophyton rubrum dengan konsentrasi $5 \%$ dan $10 \%$ tergolong sedang; konsentrasi $20 \%$ dan $40 \%$ tergolong kuat; dan konsentrasi $80 \%$ tergolong sangat kuat.

Hasil analisis post-hoc menunjukkan adanya perbedaan bermakna antara kontrol positif dengan konsentrasi $5 \%$, 10\%, 20\%, $40 \%$, dan $80 \%$; serta perbedaan bermakna antara konsentrasi $80 \%$ dengan konsentrasi $20 \%$, $10 \%$, dan $5 \%$; hal tersebut dikarenakan nilai signifikansinya $<0,05$. Perbedaan besarnya daerah hambatan untuk masing-masing konsentrasi dapat diakibatkan antara lain perbedaan besar kecilnya konsentrasi atau sedikitnya kandungan zat aktif antimikrob yang terkandung di dalam ekstrak, kecepatan difusi bahan antimikroba ke dalam medium, kepekaan pertumbuhan bakteri atau jamur, reaksi antara bahan aktif dengan medium dan temperatur inkubasi, $\mathrm{pH}$ lingkungan, komponen media, waktu inkubasi dan aktivitas metabolik mikroorganisme. ${ }^{20}$ Diameter zona hambat yang terbentuk menunjukkan bahwa terjadi peningkatan seiring dengan 
penambahan konsentrasi ekstrak, hal ini dikarenakan semakin tinggi pula kandungan zat aktif di dalamnya sehingga aktivitas antifungi akan semakin besar. Semakin tinggi konsentrasi suatu obat maka akan semakin banyak molekul obat yang dapat menduduki reseptor tempat kerja obat, sehingga respon yang dihasilkan obat tersebut akan terus meningkat hingga semua reseptor obat telah diduduki. ${ }^{21}$

Aktivitas antifungi pada ekstrak etanol daun kesum diduga disebabkan adanya efek sinergisme dari setiap metabolit sekunder yang terkandung, yaitu saponin, flavonoid, alkaloid, terpenoid, dan fenol. Metabolit sekunder tersebut memiliki potensi sebagai senyawa antifungi. ${ }^{22}$ Alkaloid merupakan senyawa yang memiliki aktivitas antimikrob dengan cara menghambat esterase, DNA dan RNA polimerase; alkaloid juga menghambat respirasi sel dan berperan dalam interkalasi DNA. ${ }^{23}$ Mekanisme kerja flavonoid dalam menghambat pertumbuhan jamur yakni dengan menyebabkan gangguan permeabilitas membran sel jamur. Gugus hidroksil yang terdapat pada senyawa flavonoid menyebabkan perubahan komponen organik dan transpor nutrisi yang akhirnya akan mengakibatkan timbulnya efek toksik terhadap jamur. $^{15}$ Saponin bekerja dalam mengganggu permeabilitas membran sel jamur. Permeabilitas yang meningkat mengakibatkan cairan intraseluler yang lebih pekat tertarik keluar sel sehingga nutrisi, zat-zat metabolisme, enzim, protein dalam sel keluar dan jamur mengalami kematian. $^{23}$ Mekanisme kerja terpenoid adalah menghambat pertumbuhan jamur patogen dengan cara merusak organel-organel sel jamur, baik melalui membran sitoplasma maupun mengganggu pertumbuhan dan perkembangan spora jamur. $^{24}$

Berdasarkan hasil skrining fitokimia pada ekstrak etanol daun kesum, diperoleh bahwa senyawa metabolit sekunder yang dominan dalam sampel penelitian ini adalah senyawa fenol. Senyawa metabolit sekunder golongan fenol dilaporkan memiliki efek antifungi terhadap beberapa jamur seperti Candida albicans, Cryptococcus neoformans, Rhizopus sp., dan Aspergillus parasiticus. ${ }^{25,26}$ Mekanisme senyawa fenol sebagai antifungi yaitu berinteraksi dengan dinding sel jamur, dimana pada kadar yang rendah akan mendenaturasi protein dan pada kadar yang tinggi akan menyebabkan koagulasi protein sehingga sel akan mati. ${ }^{14}$ Senyawa fenol dapat menyebabkan terhentinya siklus sel pada jamur yaitu pada fase replikasi sehingga menghambat pertumbuhan sel jamur, fenol menyebabkan kerusakan pada mitokondria. ${ }^{27}$

\section{SIMPULAN}

Ekstrak etanol daun kesum (Polygonum minus Huds.) memiliki aktivitas antifungi terhadap Trichophyton rubrum.

Konsentrasi yang efektif dalam menghambat pertumbuhan Trichophyton rubrum adalah konsentrasi $20 \%$.

\section{UCAPAN TERIMA KASIH}

Terima kasih kepada staff bagian Parasitologi dan Mikrobiologi Fakultas Kedokteran Universitas Tanjungpura Pontianak dan juga seluruh pihak yang terlibat dalam memberikan motivasi, bimbingan dan dalam penelitian ini.

\section{DAFTAR PUSTAKA}

1. Wolf K, Johnson RA, Saavedra A, Roh EK. Fitzpatrick color atlas and synopsis of clinical dermatology. Edisi ke-8. New York: McGraw Hill Professional; 2017. hlm.594-6.

2. Dogo J, Seniyat LH, Edward CD. Prevalence of tinea capitis among school children in nok community of Kaduna State, Nigeria. J Path. 2016;2016:1-6.

3. White $\mathrm{T}$, Matthew $\mathrm{H}$. Genomic determinants of infection competence in dermatophyte fungi. 2015. [diunduh 19 Maret 2017]. Tersedia dari: http://www.genome.gov/Pages/Research/Sequenci ng/SeqProposals/Dermatophyte WP seq.pdf

4. Abbas AK, Mohammed AZ, Mahmoud SI. Superficial fungal infection. Mustansiriya Med J. 2012;11(1):75-7.

5. Lakshmipathy DT, Kannabiran K. Review on dermatomycosis: pathogenesis and treatment. $\mathrm{J}$ Nat Sci. 2010;2(7):726-31.

6. Bertus NVP. Profil dermatofitosis di poliklinik kulit dan kelamin RSUP Prof Dr RD Kandou Manado periode Januari-Desember 2012. J eCl. 2015;3(2):731-34. 
7. Sondakh CEEJ, Pandaleke TA, Mawu FO. Profil dermatofitosis di poliklinik kulit dan kelamin RSUP Prof Dr RD Kandou Manado periode JanuariDesember 2013. J eCl. 2016;4(1):1-6.

8. Siregar RS. Atlas berwarna saripati penyakit kulit. Edisi ke-3. Jakarta: Penerbit Buku Kedokteran EGC; 2015.hlm.11-32.

9. Widaty S, Budimulja U. Dermatofitosis. Dalam: Menaldi SL, Bramono K, Indriatmi W, editor (penyunting). Ilmu penyakit kulit dan kelamin. Edisi ke-7. Jakarta: Badan Penerbit FKUI; 2016. hlm. 109-16.

10. Ridzuan PM, Ain HH, Norazian AMH, Roesnita, Aminah KS. Antibacterial and antifungal properties of Persicaria odorata leaf against pathogenic bacteria and fungi. Bentham Open. 2013;4:71-4.

11. Qader SW, Abdulla MA, Chua LS, Sirat HM, Hamdan S. Pharmacological mechanism underlying gastroprotective activities of the fractions obtained from Polygonum minus in sprague dawley rats. Int J Mol Sci. 2012;13:148196.

12. Wibowo MA, Anwari MS, Aulanni'am, Rahman F. Skrining fitokimia fraksi metanol, dietil eter dan nheksana ekstrak daun kesum (Polygonum minus). Jurnal Penelitian Universitas Tanjungpura. 2009;16(4):410-1.

13. Vikram P, Chiruvella KK, Ripain IHA, Arifullah M. A recent review on phytochemical constituents and medicinal properties of kesum (Polygonum minus Huds.). Asian Pac J Biomed. 2014;4(6):430-5.

14. Lidyawita R, Sudarsono, Harsini. Daya antifungal rebusan kulit batang jambu mete (Anacordium occidentale L.) terhadap C.albicans pada resin akrilik. Tradit Med J. 2013;18(1):46-52.

15. Oliveira VM, Carraro E, Auler ME, Khalil NM. Quercetin and rutin as potential agents antifungal against Cryptococcus spp. Brazilian $J$ Bio. 2016;76(4):1029-34

16. Pratiwi ST. Mikrobiologi farmasi. Jakarta: Erlangga; 2008. hlm. 176-85.

17. Khusnul, Hidana R, Kusmariani W. Uji efektivitas ekstrak etanol rimpang lengkuas (Alpinia galangal L) terhadap pertumbuhan Trichophyton rubrum secara in vitro. Jurnal Kesehatan Bakti Tunas Husada. 2017;17(1):73-80.
18. Puspadewi R, Adirestuti P, Menawati R. Khasiat umbi bawang dayak (Eleutherine palmifolia (L.) Merr.) sebagai herbal antimikroba kulit. Kartika Jurnal IImiah Farmasi. 2013;1:31-7.

19. Kandoli F, Abijulu J, Leman M. Uji daya hambat ekstrak daun durian (Durio zybethinus) terhadap pertumbuhan Candida albicans secara in vitro. Jurnal IImiah Farmasi Universitas Sam Ratulangi. 2016;5:46-52.

20. Salni, Nita A, Sriviona R. Isolasi senyawa antijamur dari rimpang lengkuas putih (Alpinia galanga (L.) wild) dan penentuan konsentrasi hambat minimum terhadap Candida albicans. Prosiding Semirata 2013 Fakultas Matematika dan IImu Pengetahuan Alam Universitas Lampung. 2013;301-7.

21. Rang HP, Dale MM, Ritter JM, Moore PK. Pharmacology. Edisi ke-9 London: Churchill Livingstone; 2018.hlm.6-21.

22. Ferreira MdPSBC, Cardoso MFdc, da Silva FdC, Ferreira VF, Lima ES, Souza JVB. Antifungal activity of synthetic naphthoquinones against dermatophytes and opportunistic fungi: preliminary mechanism of action tests. Ann Clin Microbiol Antimicrob. 2014;13:26.

23. Yanti N, Samingan, Mudatsir. Uji aktivitas antifungi ekstrak etanol gal manjakani (Quercus infectoria) terhadap Candida albicans. Jurnal IImiah Mahasiswa Pendidikan Biologi. 2016;1(1):1-9.

24. Moiz A, Ansari, Amiya A, Zeeshan F, Saif $H$. Natural phenolic compounds: a potential antifungal agent. Formatex. 2013;1:1189-95.

25. Romina P, Pizzolitto, Carla L, Barberis, José S, Dambolena, et al. Inhibitory effect of natural phenolic compounds on Aspergillus parasiticus growth. J Chem. 2015;1:7.

26. Wu XZ, Cheng AX, Sun LM, Lou HX. Effect of Plagiochin e, an antifungal macrocyclic bis (bibenzyl), on cell wall chitin synthesis in Candida albicans. Acta Pharmacol Sin. 2008;29:1478-85.

27. Lutfiyanti R, Widodo F, Eko N, Dewi. Aktivitas antijamur senyawa bioaktif ekstrak Gelidium latifolium terhadap Candida albicans. Jurnal Pengolahan dan Bioteknologi Hasil Perikanan. 2012;1(1):1-8 